\title{
KASVATUKSEN JA KOULUTUKSEN MANIFESTI
}

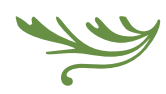

\section{KOULUTUKSEN PUOLUSTUS}

Koulutusta syytetään - eikä ensimmäistä kertaa - siitä, ettei se tuota, mitä sen pitäisi tuottaa. Hyökkäys tulee kahdesta suunnasta, populismin ja idealismin taholta. Populismin tunnistaa siitä, että se yksinkertaistaa koulutukseen liittyvät ongelmat palauttamalla ne kysymyksiksi yksilöiden mausta tai välineellisistä valinnoista. Populismi kuvaa koulutusprosessit yksinkertaisina, yksiulotteisina ja suoraviivaisina. Sen mukaan opettajat hallitsevat koulutusprosessit asettamalla tiedon ja opiskelijat oikeaan arvojärjestykseen perustaen toimintansa tutkimustuloksiin siitä, "mikä toimii".

Idealismin taas tunnistaa ylimitoitetuista odotuksista koulutuksen mahdollisuuksia kohtaan. Idealismissa koulutus liitetään tavoitteisiin toteuttaa demokratiaa, solidaarisuutta, inkluusiota, suvaitsevaisuutta, sosiaalista oikeudenmukaisuutta ja rauhaa (jopa vakavien konfliktien ja sotien repimissä yhteiskunnissa). Koulutus ei koskaan tunnu pystyvän täyttämään näitä odotuksia ja joutuu siten jatkuvasti asettautumaan puolustuskannalle.

Jotkut yrittävät vastustaa populismia idealismilla perustelemalla, että asia voidaan ratkaista laittamalla koulutuksen asialista tavoitteineen 'oikeaan' kuntoon. Toiset vastustavat idealismia populistisin väittein, että koulutus saadaan kuntoon ja toimimaan paremmilla tutkimusnäytöillä ja paremmilla menetelmillä. Molemmat näkökulmat perustuvat olettamukseen, että koulutuksessa on puutteita, jotka täytyy korjata. Kumpaankin ajattelutapaan sisältyy riski, että ne kadottavat kokonaan koulutuksen kasvatuksellisen ulottuvuuden.

Manifestimme tavoitteena on puhua kasvatuksen ja koulutuksen puolesta ilman populismia ja idealismia. Tarkoituksena on nostaa esiin huoli koulutuksen kasvatuksellisuudesta. Manifesti on kiinnostunut siitä, kuinka paljon oppilaitoksissamme on tilaa kasvatukselle.

\section{KOULUTUKSEN INTRESSI}

Esitämme, että voidakseen puhua koulutuksen puolesta kasvatuksellisella tavalla on oltava kiinnostunut vapaudesta, tarkemmin ilmaistuna toisten vapaudesta: lasten, oppilaiden ja opiskelijoiden vapaudesta. Vapaus ei tässä tarkoita rajatonta "kaikki käy" -ajattelua, eikä individualistista preferenssien ja valintojen vapautta. Vapaus on aina suhteellista ja jo lähtökohtaisesti vaikea käsite. Siksi vapaus ei koulutuksen ja kasvatuksen yhteydessä tarkoita auktoriteetin puuttumista vaan auktoriteettia, johon sisältyy suuntautuneisuus vapauteen.

Pohdinnoilla koulutuksen ja vapauden yhteydestä on pitkä historia. Alun perin koulutuksen ajateltiin kuuluvan vain niille yhteiskunnallisille ryhmille, jotka jo olivat vapaita. Valistuksesta lähtien koulutus 
alettiin itsessään nähdä vapauttavaksi prosessiksi. Tällainen vapaus projisoidaan usein tulevaisuuteen, perustellen vapauden toteutumista joko psykologiaan nojaavilla argumenteilla sisäisten kykyjen ja potentiaalin kehittämisestä, tai sosiologiaan nojaavilla argumenteilla sosiaalisesta muutoksesta parempaan, sorrosta vapautumisesta ja epätasa-arvoisuuden vähentämisestä. Näin koulutus ei ainoastaan kytkeydy muutosprosessiin, vaan siitä on tullut suorastaan muutoksen synonyymi. Mutta ymmärtämällä koulutus joksikin, mitä ei ole vielä - ymmärtämällä se prosessina, joka lunastaa lupauksensa joskus tulevaisuudessa - kysymys vapaudesta ei enää koskekaan nykyhetkeä (here and now) vaan saattaa lykkäytyä pysyvästi jonnekin tulevaisuuteen. Tämän vuoksi koulutuksen kasvatuksellisuus onkin jossakin tavoittamattomissa.

\section{KOULUTUS "SEN MIKÄ ON" JA "SEN MITÄ EI OLE" VÄLISESSÄ JÄNNITTEESSÄ}

Sen sijaan, että ajattelemme kasvatusta temporaalisena, aikaan sidottuna, käsitteenä joka jotenkin liittyy "mikä on"/"mitä ei ole vielä" väliseen jännitteeseen esitämme koulutuksen oikeaksi paikaksi jännitettä, joka sijaitsee asiaintilojen "mikä on" ja "mitä ei ole" välissä. Tällainen atemporaalinen, ajasta irrotettu, käsitys koulutuksesta voi tehdä näkyväksi sen, mitä tapahtuu, jos luovumme "mikä on" /"mitä ei ole"-jännitteestä ja ymmärrämme koulutuksen joko sellaisena, "mikä on" tai sellaisena, "mitä ei ole".

"Mikä on" -katsannossa koulutuksesta tulee yksi sopeuttamisen muoto. Näin koulutus voi olla joko sopeuttamista olemassa oleviin oloihin ("mikä on"yhteiskuntaan), jolloin koulutuksesta tulee sosiaalistamista, tai koulutus voi olla sopeuttamista yksilön omiin ominaisuuksiin ("mikä on”-yksilöön, -lapseen, -opiskelijaan), jolloin se perustuu sellaisiin "tosiasioina" otettuihin ominaisuuksiin kuin lahjakkuus, ADHD, oppimisongelmat jne. Molemmissa tapauksissa koulutukselta puuttuu kiinnostus vapauteen, kiinnostus sellaiseen tavanomaisen, jo olemassa olevan ylittävään, jossa ilmenee jotain uutta ja odottamatonta.

Ratkaisu ei kuitenkaan ole sijoittaa koulutusta "sen mitä ei ole"-kyltin alle. Niin tehdessämme kah- litsisimme koulutuksen utopistisiin unelmiin. Koulutuksen pitäminen irti utopiasta ei ole pessimismiä, vaan keino olla lastaamatta koulutuksen kannettavaksi täyttymättömiä toiveita, jotka loppujen lopuksi johtavat pikemmin vapauden karkaamiseen ulottumattomiin kuin toteutumiseen tässä ja nyt. Pitäytymällä "mikä on"/"mikä ei ole”-jännitteessä merkitsee myös vastuun ottamista nykyhetkestä. Sitomalla koulutus "siihen mikä ei ole" merkitsee vastuun luovuttamista koulutuksen ulkopuolisille voimille. Sen sijaan koulutuksen kytkeminen "siihen mitä ei ole" merkitsee vastuun siirtämistä saavuttamattoman tulevaisuuden pilvilinnoihin. Kasvatuksellisesta näkökulmasta molemmat ääripäät tuntuvat vastuuttomilta. Sen vuoksi on parasta pysyä näiden välisessä jännitteessä.

\section{NÄKEMYSRISTIRIITA,}

\section{SUBJEKTIVITEETTI JA HISTORIA}

Jännitettä ”sen mikä on” ja ”sen mitä ei ole” välillä ei tule ymmärtää pyrkimyksenä kultaisen keskitien löytämiseen kahden ääripään välillä. Sitä ei myöskään pidä ymmärtää "sen mikä on" ja "sen mitä ei ole" yhdistämisenä synteesiksi. Jännite ”sen mikä on” ja "sen mitä ei ole" välillä syntyy näiden vastakkainasettelusta. On kysymys siitä, että olemassa olevaa asiaintilaa ("mikä on") tulee häiritsemään jokin radikaalisti uusi elementti, joka ei ole jo olemassa olevan toistoa. Tämä häiriö - jota voidaan nimittää näkemysristiriidaksi (dissensus) on kohta, jossa subjektiviteetti "astuu kuvaan". Se on kohta, jossa puhuminen ei ole pelkkää aiemman toistamista eikä vakuuttamista (self-affirmation), vaan ainutlaatuista ja ainutlaatuisella tavalla uutta. Siten se on paikka, jossa vapaus astuu kuvaan.

Kun subjektiviteetti pelkistyy joksikin "mikä on", siitä tulee identiteetti ymmärrettynä samastumisena vallitsevaan järjestykseen tai jo olemassa olevaan. Kun subjektiviteetti pelkistetään joksikin "mitä ei ole", siitä tulee fantasiaa: "kuviteltu itse", joka jää ikuisesti todellisuuden ulkopuolelle. Pysyminen jännitteessä "mikä on"/"mitä ei ole" merkitsee sitä, että historia otetaan vakavasti ja koulutus ymmärretään perin juurin historiallisena. Toisin sanoen, näin koulutus ymmärretään avoimena pikemminkin uusille ja 
odottamattomille tapahtumille kuin jo olemassa olevan loppumattomalle toistamiselle tai marssina kohti ennalta määrättyä tulevaisuutta, joka ei ehkä kuitenkaan koskaan saavu.

\section{TEOREETTISET VOIMAVARAT JA KASVATUSTEORIAN KYSYMYS}

Kasvatuksen paikantaminen "mikä on" /"mitä ei ole"väliseen jännitteeseen vaikuttaa myös siihen, millaisia teoreettisia välineitä koulutus- ja kasvatustutkimuksessa voidaan ottaa käyttöön. Kyseenalaistamme sen, pystyvätkö eri akateemiset oppialat täysin ottamaan haltuunsa koulutuksen kasvatuksellista ulottuvuutta ja saada siten koulutuksen 'toimimaan'. Kun kasvatussosiologia pyrkii selittämään, miten koulutus uusintaa olemassa olevaa eriarvoisuutta - joko avoimesti tai ideologian välityksellä - se toimii ”sen mikä on” alueella. Sellaisen tiedon hyödyntäminen kasvatuksellisesti sisältää riskin, että yksilö nähdään vain "mikä on"-näkökulmasta sen sijaan, että tiedolla edistettäisiin vapautta.

Toisaalta taas kehityspsykologia ymmärtää "sen mitä ei ole" jonakin sellaisena "mitä ei vielä ole", mikä puolestaan sisältää riskin alistaa nykyinen vapaus tulevaisuudessa häämöttävälle vapaudelle, jota ei ehkä kuitenkaan koskaan tule. Molemmat teoretisoinnit ovat omiaan johtamaan koulutusta pois "mikä on"/"mikä ei ole" -jännitteestä.

Tämä panee kysymään, onko mahdollista löytää teoretisointimuotoja, jotka onnistuvat pysyttäytymään tässä jännitteessä. On kysymys aidosta kasvatustieteellisestä teoriasta erotuksen soveltavista ja muualta tuoduista teoretisoinneista.

\section{KOULUTUKSEN TEORETISOINTIA}

\section{KASVATUKSELLISESTI}

Haasteena on kehittää teoriamuotoja ja teoretisointeja, joiden intressinä ja lähtökohtana vapaus. Sellaiset teoriamuodot eivät askartele kognitiivisella alueella missä teoria sitoisi koulutuksen siihen "mikä on", eikä myöskään normatiivisella alueella missä teoria sitoisi koulutuksen siihen "mitä ei ole". Teoriamuotojen välineet ovat luonteeltaan pikemminkin eettisiä, poliittisia ja esteettisiä. Ne käsittävät subjektiviteetin etiikan, emansipaation politiikan ja vapauden estetiikan.
Subjektiviteettiuuden etiikka korostaa tapoja, joissa subjekti näyttäytyy yksilönä, vastuullisena vastauksena sille, mikä tai kuka toinen on. Emansipaation politiikka korostaa hetkeä, jossa subjekti pelkkään toistamiseen sortumatta ja ilman vakuuttamista puhuu tavalla, jo tuo maailmaan jotain uutta. Vapauden estetiikka korostaa tapaa, joka onnistuu haastamaan 'tervettä järkeä' (common sense) olettamalla tasa-arvon toteutuvan epätasa-arvoisessa tilanteessa.

\section{KASVATUKSEN PUOLESTA}

Manifestimme on yritys osoittaa, mitä merkitsee puhua kasvatuksellisesti koulutuksen puolesta. Puolustamme koulutusta vastataksemme hyökkäyksiin ja haasteisiin, joilla se yritetään sitoa joko siihen "mikä on" tai siihen "mitä ei ole", eli joko jo hyvin tuntemaamme nykyisyyteen tai jo ennalta määritettyyn, mutta aina pakenevaan tulevaisuuteen. Molemmat katsantokannat pikemminkin sulkevat kuin avaavat koulutusta kohti laajempia mahdollisuuksia.

Manifesti on yritys ilmaista, mitä voisi tarkoittaa koulutuksen puolesta puhuminen tavalla, joka näkee kasvatuksen jonakin erityisenä, ainutlaatuisena ja 'oikeana'. Tässä katsannossa manifesti yrittää tunnistaa ne haasteet, joihin joudutaan vastaamaan haluttaessa puolustaa koulutusta - mikä vuorostaan merkitsee halua puolustaa vapauden mahdollisuutta.

Raakakäännös: Johanni Larjanko

Editoiva käännös: Anneli Kajanto ja Heikki

Silvennoinen 


\section{MANIFESTI \\ KOULUTUKSEN}

PUOLESTA?

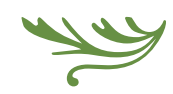

Meidän aikanamme manifestin voi esittää vain ironiana. Tiedämme hyvin, ettei yksikään kirjoitettu manifesti - oli se sitten taiteesta tai vaikka politiikasta - ole kyennyt muuttamaan maailmaa. Samalla kun manifesti puhuu korkein tavoittein - kunnianhimoisena tavoitteena se, että manifesti onnistuisi puhumaan puolestaan - sen ei pitäisi sanella, mitä pitäisi tapahtua tai mitä ei enää saisi tapahtua. Ironisena muotona - tai ironisena performanssina - manifesti voi olla vain yritys puhua ja sillä tavoin luoda avaus, hetkellinen häiriö. Juuri siihen myös manifestimme pyrkii. Emme yritä puhua vain koulutuksesta vaan myös koulutuksen puolesta.

Se ei ole ihan helppoa. Jos olisi täysin selvää, mitä koulutus tai kasvatus on ja mistä siinä on kysymys, olisi aika helppoa puhua sen puolesta, koska suurimman osan työstä se on tehnyt itse. Siksi haaste ei olekaan pelkästään puhua koulutuksesta, sen puolesta tai sen nimissä, vaan sanoa samalla jotakin asiasta, josta ja jonka puolesta ja jonka nimissä yritämme puhua.

Sen voi tehdä vaikkapa määritelmän kautta, ehdottamalla määritelmää sille mitä kasvatus on tai mitä sen pitäisi olla, ja rakentamalla argumentaatiota sen pohjalta. Ehkä juuri sitä mekin teemme manifestissamme, vaikkakin sitomalla kasvatus ja vapauden idea (vapauden, joka on 'vaikea', koska se on sidoksissa ja suhteellista) yritämme ilmaista kasvatuksellisen intressin intressinä johonkin sellaiseen, josta ei saa otetta, johonkin siinä mielessä määrittelemättömään. Positiivisemmin sanottuna, pyrimme osoittamaan, että monet nykypäivän koulutuskeskustelussa ilmenevät puhe-, toteuttamis- ja ajattelutavat - sekä yhteiskunnassa yleensä että kasvatustieteellisen tutkimuksen piirissä - ovat vaarassa sivuuttaa juuri sen, mikä voisi olla kasvatuksellisesti olennaista.

\section{POPULISTIT, IDEALISTIT JA KOULUTUS}

Sekä populistinen että idealistinen strategia tuntuu kadottavan jotain kasvatuksellisesti tärkeää - tai tarkemmin sanottuna: kumpikin tuntuu kadottavan koulutusnäkemyksessään jotain mikä saattaisi olla kasvatuksen kannalta tärkeää tai minkä pitäisi olla kasvatuksen kannalta tärkeää. Populismi odottaa koulutukselta liian vähän - ja siten se voi syyttää niitä, jotka odottavat hiukan enemmän, niitä, jotka monimutkaistavat käsitystä kasvatuksesta. Idealismi taas odottaa kasvatukselta liian paljon - ja voi siten syyttää niitä, jotka odottavat siltä liian vähän niitä, jotka sitovat koulutuksen liian herkästi vain olemassa olevaan asiaintilaan. 'Vapaus' merkitsee silloin koulutuksessa jotain 'ylimääräistä', ja siten sellaista, mistä vakaa populisti tai vakaa idealisti ei saa otetta, mutta mikä voi olla merkityksellistä kasvatuksellisesti.

Sivuhuomautuksena: sanan 'education' yksi ongelma on sen monimerkityksisyydessä. Se on erityisesti englannin kielen ongelma, sillä muissa kielissä, esimerkiksi saksassa on useampia käsitteitä, kuten Erzichung, Bildung, Ausbildung ja niin edelleen (suomessa kasvatus, sivistystyö, koulutus, valistus, suom. huom.). Emme aio käsitellä niitä kaikkia. Emme esimerkiksi pyri sanomaan, että koulujen pääasia olisi vapaus tai että ammattikoulutusta ei tulisi kutsua kasvatukseksi. Mutta kysymme, kuinka paljon kasvatusta on mahdollista tapahtua kouluissa; kuinka paljon kasvatusta voi tapahtua ammattikoulutuksessa. Ja tavallaan yritämme osoittaa, kuinka tärkeää voi olla esittää tämä kysymys, ja miksi se voi olla merkityksellinen erityisesti tässä ja nyt, kun näemme, että koulutusta vastaan hyökätään siksi, että se ei tuota sitä, mitä sen odotetaan tuottavan (ja ehkä se tuottaa myös jotain sellaista, mitä sen ei pitäisi populismin tai idealismin mukaan tuottaa).

\section{KASVATUKSELLINEN HETKI NOUSEE TÖRMÄYKSESTÄ}

Vapauden idea ei ole kasvatuksen alueella outo käsite. Siihen voi löytää paljon viittauksia läpi koko 
kasvatusajattelun ja kasvatuskäytäntöjen historian. Voimme kuulla sen kaikuja esimerkiksi emansipaation, valistuksen tai vapaan sivistystyön käsitteissä, ja voimme löytää sen antaman lupauksen kriittisessä padagogiikassa, voimaannuttavassa kasvatuksessa ja niin edelleen. Tässä mielessä vapaudella voi olla voimaa pitää kasvatus erillään siitä, mikä on todellisuutta tässä ja nyt. Siihen sisältyy myös voimaa pitää avoimena täysin uuden mahdollisuus. Samalla on kuitenkin olemassa riski, että esimerkiksi emansipaation, vapautuksen ja voimaannuttamisen käsitteissä vapaus projisoidaan aina vain tulevaisuuteen. Silloin vapaus nähdään jonakin, jonka toteutuminen vaatii aikaa, ja joka saattaa joskus todellistua, mutta joka kuitenkin on tuloillaan vasta joskus tuonnempana.

On olemassa vahva taipumus ajatella kasvatusta ja koulutusta vain temporaalisena, aikaan sidottuna sekä suhteessa siihen mitä sen pitäisi tuottaa (tuleva vapautuksen tila, tuleva valistuksen tila) että suhteessa sen kohteeseen (lapseen sellaisena, joka 'ei vielä ole' sellainen kuin tavoitellaan). Pitäisikö temporaalisuus, ajallinen sidos, kokonaan irrottaa kasvatuksesta ja koulutuksesta, jotta voisimme saada otteen juuri kasvatuksellisesti tärkeästä? Jostakin joka ei ole vain sitä, mikä jo on olemassa, eikä sitä, mikä ei vielä ole olemassa (mutta joka saattaa todellistua jonakin päivänä)?

Jos vapaus otetaan vakavasti - sellaisena joka voi toteutua juuri tässä ja nyt - silloin ehkä kasvatuksellinen momentum, kasvatustapahtuma, nousee esiin "mikä on" /" mikä ei ole”-välisestä törmäyksestä; se on juuri tässä ja nyt. Rancièrea mukaillen tämä vastakohtaisuuteen perustuva törmäys, johon viittaamme näkemysristiriitana, on hetki jolloin uutta luova puhuminen - erotuksena aiemman toistamisesta - voi toteutua. Sei tarkoita hetkeä, jossa olemassa olevat identiteettipositiot rakennetaan toistamalla, eikä kyse ei myöskään ole tulevaisuuden lupauksesta. Kyse on pikemminkin esityksestä, joka tapahtuu tässä ja nyt, aivan meidän edessämme. Tämä ei tarkoita - kuten pyrimme osoittamaan - historian ottamista pois kasvatuksesta, vaan pikemminkin historian ottamista vakavissaan - se on uskomista siihen, että voimme itse tehdä historiaa, koska historia ei ole ennalta laaditun ohjelman toimeenpanemista, vaan toisiaan seuraavien tapahtumien ketju.

\section{MIKÄ ON KASVATUKSELLISTA KOULUTUKSESSA?}

Manifesti ei vain pyri puhumaan kasvatuksen puolesta, eikä se pyri vain kuvaamaan puolustamaamme kasvatusta, vaan manifestin kohteena on ehkä myös kasvatuksen teoria, joka ennen muuta pyrkii konstruoimaan kasvatuksellisen 'objektin', kasvatustieteen kohteen. Tämäkin on tärkeää, sillä mikäli ei ole kasvatuksellista tapaa puhua koulutuksesta, eikä kasvatustiettellistä tapaa teoretisoida koulutusta ja kasvatusta, silloin ainoat käytettävissä oleviksi ajattelun ja tutkimuksen välineiksi jäävät ne, jotka on lainattu jostain muualta. Kasvatustieteen teorian ja kasvatustieteen tutkimuksen alueella sellaiset välineet lainataan usein muilta akateemisilta tieteenaloilta, ja niiden varaan ovat rakentuneet kasvatussosiologia, kasvatuspsykologia, kasvatusfilosofia, kasvatuksen historia, koulutuksen talous ja niin edelleen. Näillä välineillä voidaan toki saada näkyviin tärkeitä asioita ja tehdä tärkeää työtä. Mutta on tarpeellista esittää uudelleen kysymys - aivan kuten kysyimme kasvatuksen käytännöistä - voivatko nämä teoreettiset välineet tavoittaa koulutuksen kasvatuksellista ulottuvuutta. Olemme epäileväisiä, mutta tärkeintä meidän mielestämme on nähdä, miten mielekäs seuraava kysymys voi olla: miten hyvin kasvatussosiologia, kasvatuspsykologia, kasvatusfilosofia, kasvatushistoria ja muut vastaavat voivat ymmärtää sen, mikä koulutuksessa ja kasvatuksessa on kasvatuksellista?

Totesin aiemmin, että manifestimme on pyrkimys puhua kasvatuksen puolesta. Tietyllä tavalla se onkin sellaista, jonka voi vain tehdä, ei sellaista minkä voi selittää. Siinä mielessä tämä kommentaari on yhtä paljon pyrkimys puhua kasvatuksen puolesta kuin itse manifestikin. Se on siis myös yhtä paljon manifesti kuin se manifesti, josta se pyrkii tekemään vakuuttavan. Siitä syystä emme hae manifestiin kannattajien allekirjoituksia. Manifesti pikemminkin kutsuu ihmiset puhumaan kasvatuksesta. Se kehottaa moninaistamaan, ei kopioimaan.

Käännös: Eeva Siirala; editoiva käännös:

Anneli Kajanto ja Heikki Silvennoinen

\section{Gert Biesta}

kasvatustieteen professori, The Stirling Institute of Education, Stirlingin yliopisto, Skotlanti, UK 
CARL ANDERS SÄFSTRÖM

\section{MANifESTI}

\section{KOULUTUKSEN}

PUOLESTA!

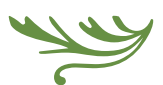

Modernin koulutuksen katsotaan liittyvän modernin hyvinvointivaltion kehitykseen. Jo Pohjois-Amerikan sulatusuunin varhaiset pragmaatikot näkivät koulutuksen ponnahduslautana uuteen ja parempaan yhteiskuntaan. Teknologiasta oli tuleva veturi, ja koulutuksen tuli valmistaa maaperä tällaiselle uudelle yhteiskunnalle (Feinberg 1975). Arvot ja normit, joiden kautta tämä uljas uusi maailma muodostuisi, perustuivat teknologian kykyyn saada ihmiselo saavuttamaan tavoitteensa sulavammin ja tehokkaammin. Toteutettiin laajoja tutkimusprojekteja ja kehitettiin uusia menetelmiä suurten aineistojen käsittelyyn. Oli tarve sekä rakentaa että kontrolloida uudentyyppisen kansalaisen synnyttämistä - modernin, demokraattisen ihmisen. Toinen maailmansota oli osoittanut tällaisen uuden ihmisen tarpeen. Hän eroaisi fasisteista ja natseista (Herrman 1995). Modernin maailman uusien teknologioiden ruokkimat sosiaalitieteet kehittyivät nopeasti sotilasbudjettien taloudellisella tuella (Herman 1995). Ruotsissa esiin nousevat sosiaalitieteet, muiden muassa kasvatustiede, hakivat Yhdysvalloista oppia voidakseen käsitellä uusin menetelmin laajamittaisia aineistoja, joita tarvittiin suorittamaan kaksoistehtävää - luomaan ja kontrolloimaan uutta demokraattista ihmistä, jotta tämä olisi sopiva uuteen, syntyvään hyvinvointivaltioon (Säfström 2004)

Miksi tämä lyhyt historiallinen johdanto? Se on välttämätön tausta, jotta ymmärtäisimme, mitä Ruotsin koulutuksessa tänään tapahtuu. Keskeinen oival- lus on, että koulutus muotoutuu modernissa valtiossa sen mukaan, miten valtio käsittelee sisäisiä ongelmiaan ja tavoitteitaan siis miten se rakentaa kansalaisiaan säilyäkseen tietynlaisena valtiona (Popkewitz 2008). Koulutus ei ideana eikä tietynlaisena järjestelmänä ole modernin hyvinvointivaltion luomisen ulkopuolella koulutus on sen varsinaista perustaa. Näistä kahdesta seikasta seuraa ensinnäkin se, että jos koulutusta kohtaan hyökätään, koko hyvinvointivaltion ideaa kohtaan hyökätään. Se, että juuri tästä on kyse, näkyy hyvin selvästi Ruotsissa nyt, kun yhtenäinen peruskoulu ei enää olekaan kaikkien intressissä ihanne on kuitenkin muovannut 1940-luvulta lähtien koulutuspolitiikkaa - vaan perheet valitsevat koulun sosiaalisen statuksensa ja varallisuutensa perusteella (Englund 2010). Valtio rahoittaa niin kutsuttuja "vapaita kouluja", jotka noudattavat valtakunnallista opetussuunnitelmaa ja saavat rahoitusta valtion verotuloista. Ne ovat yksityisomisteisia yrityksiä tehden näin verorahoilla tulosta omistajiensa voitoksi. Sanomalehtien julkaisemien tietojen mukaan koulun perustaminen on tuottoisinta liiketoimintaa Ruotsissa. Siinä on matalin riski ja korkein tuotto. Valtakunnallinen Dagens Nyheter (29/09/2010) esimerkiksi kertoo keskimääräisen tuoton olevan 13 prosenttia yksityisissä kouluissa ja hoiva-ammateissa, kun kaikkien muiden yritysmuotojen keskimääräinen tuotto oli 9 prosenttia. Svenska Dagbladet (7/8/2010) raportoi riskipääomittajien vahvasta noususta vapaiden koulujen markkinoilla, koska se antaa korkeita tuottoja pienillä investoinneilla.

Aiempaa koulutuksen perusideaa - 'koulu kaikille' yhdistettynä demokratiaan, solidaarisuuteen ja oikeudenmukaisuuteen - liberaali ja konservatiivinen koulupolitiikka kutsuu 'hötöksi' (ruotsiksi flum / englanniksi fluff). Tällainen uusnimittely on saanut julkisuudessa varsin suuren suosion. Se on Ruotsissa osa kasvatusta ja koulutusta koskevan keskustelun muutosta, jossa aiemman demokratian sijaan avainkäsitteitä ovat 'kuri' ja 'järjestys' (Månsson \& Säfström 2010). Täsmällisemmin sanottuna 'koulu kaikille' on korvattu käsitteillä 'kaikkien tulee osallistua' ja 'elinikäinen oppiminen tietoyhteiskunnassa'. Tämä on selkeästi aiemmasta eroava puhetapa, ja sitä leimaa paluu 'positivistiseen' tietoon, jota 
tuottaa aivotutkimus, 'näyttöperusteinen tutkimus', positivistinen psykologia ja johtajuus- ja tehokkuusajatukset kaikissa koulutusta koskevissa asioissa.

\section{UHKANA TUTKIMUSALUEIDEN KAPEUTUMINEN?}

Koulutusta kohtaan tulevasta hyökkäyksestä seuraa myös toinen asia. Kun kasvatustieteellinen tutkimus sisältyy tietynlaisen hyvinvointivaltion ideaan, jonka ydintä uhkaavat poliittiset voimat oikealta - sekä liberaalit että konservatiivit - myös kasvatustieteellinen tutkimus on uhattuna. Kaikki sellaiset tutkimussuunnat, jotka suuntautuvat rajatun tutkimuskohteen ulkopuolelle (esimerkiksi suuntautuminen oikeudenmukaisuuteen, solidaarisuuteen, demokratiaan tai vapauteen) kyseenalaistetaan. Eli tutkimus supistuu sellaisen tutkimuksen hyväksi, jota poliitikot voivat käyttää määritelläkseen, mihin suuntaan asioita pitäisi tulosten perusteella muuttaa (Biesta 2010).

Ruotsissa tämä merkitsee itse asiassa sitä, että uusi oikeisto määrittelee uudelleen koko hyvinvointivaltion idean sisältäpäin muuttamalla koulutuksen koko perusrakenteen. Tähän kuuluu koululainsäädännön ja arvostelujärjestelmän muuttaminen, opettajien oikeus rangaista oppilaitaan, lukion ja yliopiston sisäänpääsykriteerien muuttaminen, kasvatustieteen tutkimuksen rahoituksen myöntämisen perusteet, opettajankoulutusohjelmat ja se, kenellä on oikeus myöntää opettajatutkintoja, yliopistojen uuden 'laatujärjestelmän' luominen ja toimeenpano, sekä monet muut seikat. Se koskee koko koulutusmaiseman muuttamista päiväkodeista aina korkeakoulutukseen saakka.

Ironista tässä kaikessa on se, että saadakseen tämän perusteellisen muutoksen aikaan, oikeistokoalition puolueiden pitää hyökätä voimakkaasti kasvatustieteellistä tutkimusta kohtaan, koska suuri osa siitä on Ruotsissa tehty kattavan 'sosiaalidemokraattisen' hyvinvointivaltion idean puitteissa (Rosengren \& Öhngren 1997). Tai oikeastaan valtion tulee määritellä uudelleen kasvatustieteellinen tutkimus, jotta se soveltuisi paremmin sen uusiin tavoitteisiin. Tätä on tehty räikeimmin edistämällä aivotutkimusta ja positivistisen kasvatuspsykologian vanhaa muotoa (Säfström 2011). Siten valtio tukee sellaista tutki- musta, joka vain vaivoin pystyy sanomaan mitään todellista kasvatuksesta ja jota voidaan helposti syyttää vain jo poliittisesti päätettyjen näkemysten legitimoimisesta siinä, mitä varten koulutusta annetaan ja mitä sen tulisi edistää. Tätä tieteellisen uskottavuuden puutetta (ja se on erityisen ironista, koska opetusministeriö väittää, että se toimii näin nimenomaan edistääkseen tutkimuksen uskottavuutta) korvaa tiukka ja aggressiivinen propaganda, jota tukee Ruotsin suurimpiin päivälehtiin kuuluva Dagens Nyheter (katso Wiklund 2006). Lehti itse asiassa muuntaa koulupolitiikan pelkäksi populismiksi ja häpeällisesti ja perusteettomasti kritisoi valtavirran vahvaa kasvatustieteellistä tutkimusta siitä, että se ei yllä tietylle 'laatutasolle'. Pitäisi kuitenkin muistaa, että tämän kritiikin ja hyökkäyksen kohde ei ole kasvatustieteellinen tutkimus sinänsä, vaan tietynlaiseksi rakennettu "sosiaalidemokraattinen" hyvinvointivaltio.

\section{TUTKIMUS KUULUU}

\section{PÄIVÄNPOLITIIKAN ULKOPUOLELLE}

Ja tässä tulen asian ytimeen. Kasvatustutkimus muotoutuu liian helposti päivänpolitiikan mukaiseksi pikemmin kuin sellaisen ajattelun tradition mukaiseksi, joka on vanhempaa kuin vallassa olevien puolueiden aikajänne. Kasvatustieteellinen tutkimus kutistuu liian helposti muualta tulevien ideoiden soveltamiseksi, on se muu sitten politiikka tai joku muu yhteiskunnan alue. Se heikentää koulutuksen kykyä vastustaa ideologisia hyökkäyksiä. Varteenotettavaa tutkimusta sekä valtavirtaista että 'kriittistä' - tekevät kasvatustieteilijät eivät osanneet ennakoida, mitä oli tulossa. Tätä suoraan päin tullutta hyökkäystä kaikkea sitä vastaan, mitä he olivat pitäneet pyhänä, ei yksinkertaisesti ollut mahdollista vastustaa millään tavoin. Tai täsmällisemmin: mahdollinen vastaus olisi vain näyttänyt vahvistavan sen, mitä uusi oikeisto väitti, nimittäin, että kasvatustiede vain yrittää vahvistaa vanhanaikaista hyvinvointivaltiota omien 'vasemmistolaisten' intressiensä mukaisesti. Muutamat tutkijakentältä tulleet vastineet vain vetivät laatijansa syvemmälle lokaan.

Vielä monimutkaisemmaksi asian tekee se, että Ruotsissa kasvatustieteen tutkimusta vastaan hyökätään myös alan sisältä. Muut tieteenalat tulevat 
kasvatustieteeseen ainedidaktiikan mukana, usein tekemättä kuitenkaan kotiläksyjään, välittämättä perehtyä kasvatustieteen teorioihin niiden intellektuaalisen historian kautta ja tuntematta, mitä on tehty ja tehdään par'aikaa kasvatustieteen alalla, kansallisesti ja kansainvälisesti. Tämä 'kasvatustieteen' tutkimuksen laajentuminen yliopistoissa, pääasiassa opettajankoulutuksen kautta, itse asiassa hämärtää asioita vielä lisää. Kasvatustiede intellektuaalisena traditiona on vakavasti marginalisoitu, ja uusia innovaatioita ilmaantuu jatkuvasti vastaamaan hämmentyneen kentän ja päättäväisten poliitikkojen vaatimuksiin. Näitä innovaatioita kutsutaan esimerkiksi ainedidaktiikaksi, kasvatustyöksi, kasvatussosiologiaksi, erityispedagogiikaksi, kasvatuspsykologiaksi ja ne ovat vakiintuneet omiksi tutkimusalueikseen. Usein niiden sama sisältö on vain nimetty eri tavalla eri yliopistoissa, ja ne kaikki on selkeästi eriytetty kasvatustieteestä (ruotsiksi "pedagogik"), mikä on omiaan hämmentämään opiskelijoita ja henkilökuntaa kaikilla tasoilla. Tavallaan tätä hajanaista kenttää pitää kuitenkin tänä päivänä kasassa valtion tavoite, ei vain tukea tietynlaista tutkimusta, vaan itse asiassa määritellä, mitä tämän tutkimusalan tulee tutkia ja selittää, miten sen tulee selittää ja minkä teorian avulla se vakiinnuttaa nämä selitykset totuuksiksi (katso lisää Säfström 2010). Mutta onko tämä sitä, mitä haluamme kasvatustieteen merkitsevän? Uskon todella, että ei ole. On aika ryhtyä puolustamaan kasvatustiedettä!

\section{Käännös: Eeva Siirala \\ Väliotsikot: toimitus \\ Carl Anders Säfström \\ kasvatustieteen professori, \\ Mälardalenin yliopisto, \\ Ruotsi; vieraileva professori, \\ Stirlingin yliopisto, UK}

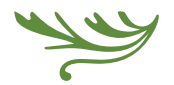

\section{LLinE}

\section{Lifelong Learning in Europe}

TARJOUS Aikuiskasvatuksen lukijoille!

LLinEn vuositilaus (neljä lehteä; sisältää postikulut)

tutustumistarjouksena $35 €$ (norm. $48 €$ )!

Lähetä viesti "AK-kampanja" osoitteeseen markus.palmenakvs.fi.

Tarjous on voimassa vuoden 2011 loppuun ja koskee uusia tilauksia.

LLinE on ainoa eurooppalainen tiedettä ja käytäntöä yhdistävä aikuiskasvatuslehti.

Se tarjoaa lukijalleen ainutlaatuisen näköalan elinikäisen oppimisen tutkimukseen, innovaatioihin ja politiikkaan.

"...an excellent role in the adult learning community." Tri Michael Sommer, InfoNet-uutispalvelu

“...our window to Europe". Prof. Miomir Despotovic, varadekaani, Belgradin yliopisto

"...Essential reading." Prof. Alan Tuckett, ICAE 